2-utvalget er tydelig på at man i hovedsak ikke skal prioritere etter alder (pkt. 8.9.2 og 8.11). Absolutt prognosetap målt i QALY kan altså ikke være riktig fortolkning. Derimot vil forventet tap av QALY som prosent av forventede gjenstående QALY harmonere godt med det Lønning 2-utvalget i sum skrev om alvorlighetsgrad og om alder.

\section{Erik Nord}

erik.nord@fhi.no

Erik Nord (f. 48) er dr.philos., seniorforsker ved Nasjonalt folkehelseinstitutt og professor II i helseøkonomi ved Universitetet i Oslo. Han er rådgiver for Helsedirektoratet og Statens legemiddelverk i arbeidet med veiledere i helseøkonomiske analyser og er også brukt av bl.a. engelske og tyske helsemyndigheter som rådgiver i slike spørsmål.

Ingen oppgitte interessekonflikter.

\footnotetext{
Litteratur

1. Olsen JA. Hva menes med «sykdommens alvorlighetsgrad»? Tidsskr Nor Legeforen 2013; 133: 64-7.

2. Wyller VB. Helseøkonomiens grunnutfordringer. Tidsskr Nor Legeforen 2013; 133: 8 .

3. Norges offentlige utredninger. Prioritering på ny. NOU 1997: 18.
}

Publisert som rask respons i nettutgaven 11.1. 2013

\section{Bruun Wyller svarer:}

Min leder om helseøkonomi har motivert seks professorer til å skrive tre innlegg der retorikken blomstrer mens sakligheten lider. Hvorfor denne opprørthet? Stoler de ikke på kraften i egne argumenter?

Min utfordring var tredelt. For det første: Er helseøkonomiske størrelser innholdsvalide? Kan for eksempel livskvalitet angis på en endimensjonal skala, slik QALY (kvalitetsjusterte leveår) forutsetter? Abel Olsen og medarbeidere skriver belærende at «som forskere bør vi være mer opptatt av kunnskapsgrunnlaget». Selvsagt. Kom med det. Deres bidrag så langt er en australsk rapport (1) som slår fast at «(...) little has been written in economics about content (or descriptive) validity» (s. 24). Vi ignoranter som ikke forstår oss på helseøkonomi, venter fremdeles på studier som beviser at menneskelig lykke kan uttrykkes i en brøk.

For det andre: Bidrar helseøkonomiske analyser til å kamuflere politiske verdivalg? Abel Olsen og medarbeidere har «ingen holdepunkter for» at så har skjedd. Men hvor er kunnskapsgrunnlaget for denne påstanden? Kanskje det ikke finnes? Det som derimot er dokumentert, er de siste tiårenes overføring av makt fra politisk nivå til ekspertnivå (2). Jeg mistenker noen helseøkonomiske miljøer for å bifalle denne maktoverføringen. Hvis denne mistanken er grunnløs, slik mine kritikere mener, må det bety at deres eget fag misbrukes. For hvordan kan man ellers forklare spredningen av helseøkonomisk tenkning til både den politiske og den medisinske arena? Er ikke helseøkonomene bekymret for at deres metoder blir anvendt på uegnede problemstillinger? Ser de ikke risikoen for at ikke-målbare fenomener - blant dem politiske verdivalg - kan overses eller forvrenges?

Dette bringer meg til min tredje utfordring: Bidrar utbredelsen av helseøkonomisk tenkning til en pervertering av rettferdighetsbegrepet? Jeg har aldri avvist at rettferdighet i politisk forstand handler om rasjonell fordeling av goder og byrder. Men i medisinen har rettferdighet et annet innhold, fordi fagets primære siktemål er den enkelte pasient, ikke nasjonalbudsjettet. Et slikt alternativt perspektiv har også samfunnet behov for. Min og andres uro gjelder derfor helseøkonomiens monopoliseringstendenser - «markedets oppnådde samfunnsmakt bidrar til samfunnets avmoralisering» (3). Abel Olsen og medarbeidere forsøker å trivialisere dette alvorlige spørsmålet. Men bekymringen er ikke basert på to tilfeldige filo- sofer, men på to alternative moralfilosofiske systemer - nærhetsetikken (4) og dydsetikken (5). Bekymringen blir ikke mindre av at ledende representanter for det helseøkonomiske faget ikke viser vilje til refleksjon over eget ståsted.

\section{Vegard Bruun Wyller \\ brwylle@online.no}

Vegard Bruun Wyller (f. 1972) er postdoktorstipendiat ved Kvinne- og barneklinikken, Oslo universitetssykehus, Rikshospitalet, og medisinsk redaktør i Tidsskriftet.

Ingen oppgitte interessekonflikter.

\section{Litteratur}

1. Richardson J, McKie J, Bariola E. Review and critique of health related multi attribute utility instruments. Research Paper 64/2011. Melbourne: Centre for Health Economics, Monash University, 2011

2. Østerud $\emptyset$. Selle P. Power and democracy in Norway: the transformation of Norwegian politics. Scand Polit Stud 2006; 29: $25-46$

3. Vetlesen AJ, Henriksen JO. Moralsk verdi blir privat, økonomisk verdi blir herre. Aftenposten 17.8.2003

4. Bauman Z. Postmodern ethics. Oxford: Blackwell, 1993.

5. Maclntyre A. After virtue. Notre Dame, IN: University of Notre Dame Press, 1984.

\section{Riktig definisjon av p-verdi?}

I en leder i Tidsskriftet i nr. 1/2013 hevder Eva Skovlund at en p-verdi vil gi svar på følgende spørsmål: «Hva er sannsynligheten for at det resultatet vi observerer (eller et enda «skjevere» resultat) har oppstått på grunn av tilfeldighet?» (1). Dette stemmer ikke, p-verdien sier ingenting om sannsynligheten for at et resultat er tilfeldig eller ikke.

En p-verdi gir derimot svar på spørsmålet: Hva er sannsynligheten for å få en testverdi som er minst like stor som den vi faktisk observerte, gitt at nullhypotesen er sann.

\section{Carl Haakon Samuelsen}

carl@linkmedical.no

Carl Haakon Samuelsen (f. 1983) har m. phil. i helseøkonomi og er helseøkonom i LINK Medical Research.

Ingen oppgitte interessekonflikter.

\section{Litteratur}

1. Skovlund E. Spør først, regn siden. Tidsskr Nor Legeforen 2013; 133: 10.

Publisert som rask respons i nettutgaven 17.1. 2013

\section{E. Skovlund svarer:}

Det var ikke helt uventet av enkelte ville reagere på min formulering. Samuelsens definisjon er selvfølgelig den formelt korrekte. Bakgrunnen for mitt valg er følgende: I medisinske artikler omhandler hovedtyngden av rapporterte p-verdier en sammenlikning av to grupper, og nullhypotesen er nesten uten unntak at sant gjennomsnitt eller andel er lik i de to gruppene. I denne sammenhengen er min formulering dekkende. Det lave presisjonsnivået er valgt med hensikt. Den formelle definisjonen finner man i alle lærebøker i statistikk.

\section{Eva Skovlund}

eva.skovlund@farmasi.uio.no 
Eva Skovlund (f. 1959) er avdelingsdirektør ved Nasjonalt folkehelseinstitutt og professor II ved Universitetet i Oslo.

Ingen oppgitte interessekonflikter.
Litteratur

1. Pedersen W. Alkoholavholdende - en risikogruppe? Tidsskr Nor Legeforen 2013; 133: $33-6$.

2. Veum E. Nådeløse nordmenn. Statspolitiet. Oslo: Kagge forlag, 2012.

Publisert som rask respons i nettutgaven 14.1. 2013

\section{W. Pedersen svarer:}

I artikkelen Akoholavholdende - en risikogruppe? viser jeg at unge voksne som ikke har brukt alkohol er kjennetegnet av bl.a. ensomhet, angst og depresjon og at det er en forhøyet andel som mottar trygdeytelser. I diskusjonen antyder jeg at dette kan skyldes at de allerede $\mathrm{i}$ utgangspunktet har kjennetegn som gjør at de ikke debuterer med alkohol, eller at de utsettes for sosiale sanksjoner fordi de ikke drikker. Jeg sier eksplisitt at det ligger langt utenfor artikkelens tema å besvare spørsmålet om kausalitet, men peker på at tidligere studier har gitt støtte til begge forklaringer. Ulike personlighetstrekk kan predikere avhold. Men alkoholavholdende kan også møtes med mistro og støtes ut av sosiale sammenhenger.

Det er overraskende at ingen av de to kommentatorene synes å ha fått med seg dette. Artikkelen fikk betydelig oppmerksomhet i mediene, hvor de fleste hadde fått med seg dette poenget. Jeg ble også av flere journalister bedt om å fortolke funnene. Jeg vektla da dette: Alkohol er en tatt-for-gitt-del av mye sosialt samvær her i landet. Det kan nok tenkes at bestemte faktorer kan predikere avhold, men det er liten tvil om at ikke-bruk av alkohol ofte fremstår som et sosialt avvik som gjerne krever begrunnelser og som i neste runde uansett kan innebære negative sanksjoner. Derimot er det tegn på at etniske grupper med muslimsk tro i økende grad fremstår som rollemodeller for avhold, også for etnisk norsk ungdom. Dette er oppløftende. Sammenhengene er selvsagt sosialt skapte og kan derfor også endres.

\section{Willy Pedersen}

willy.pedersen@sosgeo.uio.no

Willy Pedersen (f. 1952) er professor i sosiologi ved Universitetet i Oslo. Ingen oppgitte interessekonflikter.

\section{Eldre piloter, yrkessjåfører - og leger}

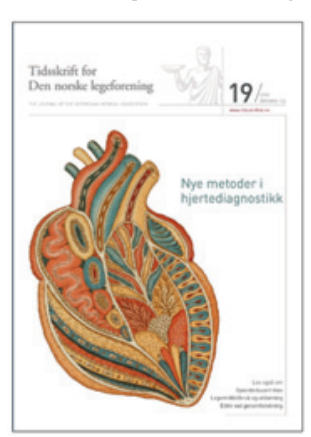

I Tidsskriftet nr. 19/2012 refererer Lars Tjensvoll til mitt spørsmål om hvem som skal sitte i et utvalg som skal vurdere egnethet av oss eldre (1). Til det er å svare at jeg er rimelig sikker på at det blant leger under 75 år finnes flere enn blant dem over 75 år med de lidelser som bør føre til at man ikke får forlenget lisens.

Lars Tjensvoll kommenterer også overskriften på mitt innlegg i Tidsskriftet nr. 12/2012 - Leger mot leger? (2). Til informasjon så jeg selv den overskriften for første gang da jeg åpnet bladet. Den er altså laget i redaksjonen. Men det gjør den ikke mindre interessant.

Debatten startet i Tidsskriftet nr. 8/2011, der Tjensvoll argumenterte for at leger burde fratas autorisasjonen på 75-årsdagen (3). Unntaksvis kunne det gis forlengelse etter gitte kriterier. Disse er: Legen må ikke lide av demens, nevrologisk sykdom, symptomgivende kreft, psykiatrisk sykdom, synsforstyrrelse eller annet som kan påvirke vurderingsevnen.
Fred Andersen (f. 1943) er dr.med. og medisinsk rådgiver ved Árran Lulesamisk senter og førsteamanuensis ved Institutt for Samfunnsmedisin, Universitetet i Troms $\varnothing$.

Ingen oppgitte interessekonflikter. 